\title{
TEMATYKA LISTÓW ŚW. RAFAŁA KALINOWSKIEGO DO RODZINY
}

Listy św. Rafała Kalinowskiego są pierwszorzędnym źródłem do poznania jego osoby i drogi świętości. Jak dotąd nie zostały one dostatecznie przebadane pod kątem jego duchowości. Odbyło się już wiele sympozjów poświęconych jego osobie, napisano kilka prac naukowych, jednak prawdziwe duchowe oblicze Józefa Kalinowskiego wciąż nie zajaśniało pełnym blaskiem przed światem. Ufamy, że poniższy artykuł, jakkolwiek nie skupia się ściśle na duchowości św. Rafała Kalinowskiego, może stać się przyczynkiem do poznania jego życia i duchowości.

Wziąwszy pod uwagę charakter i długość artykułu, jesteśmy zmuszeni do dokonania subiektywnej selekcji listów Świętego. Po ogólnym spojrzeniu na całość ograniczymy się do tych, które pisał do jedynego rodzonego brata - Wiktora, oraz jego żony Masi. Z nimi miał najbardziej bezpośredni i wręcz wylewny kontakt. Tak powstały zbiór dotyczy niemal wyłącznie ( $z$ dwoma wyjątkami) życia Józefa przed wstąpieniem do Karmelu, i obejmuje ponad 30 listów z lat 1856-1880. Ponieważ wszystkie zostały napisane przez tę samą osobę, z tą samą duchową wrażliwością, odnajdziemy w tym zbiorze pewien wspólny mianownik.

\section{Rodzina Józefa Kalinowsieiego}

Niektóre listy Józef Kalinowski napisał do konkretnych osób z rodziny, jak ojciec, macocha, brat, bratowa; inne natomiast zostały zaadresowane po prostu do rodziny i miały być przeczytane przez wszystkich.

Na końcu drugiej części pierwszego tomu listów zamieszczono genealogię rodziny Kalinowskich ${ }^{1}$, a konkretnie trzy jej pokolenia, począwszy od Andrzeja Kalinow-

1 J. Kalinowski, Listy, t. I, cz. II (1873-1877), wyd. Cz. Gil, Lublin 1978, s. 348. 
skiego (1805-1878), ojca Józefa, po jego wnuków. Wynika z niej, że pierwsza żona pana Andrzeja zmarła w roku narodzin Józefa, a więc 1835; druga w roku 1845. Gdy zatem Józef pisał do matki, chodziło o macochę, Zofię z Puttkamerów. Pan Andrzej miał w sumie dziewięcioro dzieci. Józef był drugim synem $z$ pierwszego małżeństwa i miał starszego brata Wiktora, ożenionego z Marią Gruszecką - Józef nazywał ją Masią i napisał do niej kilkanaście listów. Z drugiego małżeństwa pan Andrzej miał trójkę dzieci: Emilię, która pozostała panną, Karola, dwukrotnie żonatego, oraz Gabriela, ożenionego raz; z trzeciego małżeństwa miał jeszcze czwórkę: Marię i Monikę, które pozostały pannami, Aleksandra, ożenionego raz, i najmłodszego Jerzego, który został kapłanem. Te właśnie osoby składają się na rodzinę o. Rafała Kalinowskiego.

\section{Ogólna charakterystyka listów}

Liczba. „Zachowana korespondencja św. Rafała Kalinowskiego - ponad 1700 listów i kartek pocztowych, ponad 2 tysiące stron druku z prawie całego okresu jego dojrzałego życia - 1856 do śmierci - zawiera niezwykle bogaty materiał autobiograficzny"2. „Czytelnik łatwo zorientuje się w różnicy między listami Józefa Kalinowskiego i o. Rafała. Pierwsze z nich bardzo często mają formę dziennika. Było to zrozumiałe. Autor pisał je z dala od rodziny, która oczekiwała od niego szczegółowych wiadomości. I on spełniał te oczekiwania. Ponadto listy zastępowały mu rozmowę z najbliższymi. Nie tylko więc pisał o tym, co się wokół niego dzieje, ale wyjaśniał racje swoich wyborów, tłumaczył się z nich, odkrywał siebie. W listach zakonnych takiej potrze-

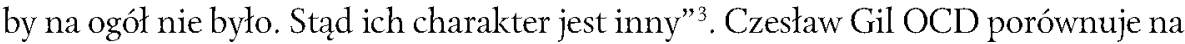
przykład jego relacje z zesłania z relacjami innych sybiraków, twierdząc, że u Józefa „w listach z katorgi i zesłania nie ma tej grozy”. „Wyjaśnienie jest proste. Wszystkie listy przechodziły przez cenzurę. Jeżeli autor chciał, aby list doszedł do adresata, nie mógł pisać pełnej prawdy"4.

Można by tę uwagę nieco skorygować. Listy innych zesłańców też były cenzurowane, a nasz zasłużony historyk, śp. o. Czesław Gil, twierdzi, że te pisane przez Józefa bardzo się od nich różniły. Nie widać jednak wielkiej różnicy pomiędzy jego listami, które przechodzily przez cenzurę, i tymi podanymi okazją, z pominięciem cenzorów. Należałoby to wyjaśnić raczej odmiennym niż u reszty sybiraków podejściem Józefa do trudnych doświadczeń. Zostało to potwierdzone przez Kościół jego beatyfikacją w roku 1983 na krakowskich Błoniach i kanonizacją w Rzymie w 1991 roku.

Tenże, Kartki z Księgi mojego życia, oprac. Cz. Gill, Kraków 2007, s. 8.

Tamże, s. 9.

Por. tamże. 
Klucz podziału. Przygotowane do druku przez o. Czesława Gila listy zostały wydane przez Towarzystwo Naukowe KUL w latach 1978-1986 w dwóch podzielonych na dwie części tomach. Tom I obejmuje okres świecki jego życia, do roku 1877, natomiast tom II okres życia zakonnego aż do śmierci w roku $1907^{5}$. Najwcześniejsze listy pochodzą z roku 1856, gdy po ukończeniu Szkoły Inżynierii Wojskowej w Petersburgu Józef Kalinowski objął w niej obowiązki asystenta ${ }^{6}$.

Okres świecki. Na dwie części tomu I, obejmującego około 20 lat, składa się 428 listów ${ }^{7}$. O. Gil dokładnie wylicza ich adresatów i stwierdza, że niemal wszystkie pisane były do rodziców i rodziny, natomiast te do osób trzecich stanowią rzadkość. Wiele listów Kalinowski spalił, zwłaszcza podczas ostatniej choroby w Wadowicach.

W odniesieniu do listów z katorgi (zachowało się ich ponad 30) o. Gil zauważa, że wówczas Kalinowski mógł pisać tylko co kwartał. Dlatego jego listy z Usola (1865-1868) są dłuższe, zwykle powstawały przez wiele dni. Ponadto były cenzurowane, więc „czytelnik listów z tego okresu musi stale pamiętać, że przechodziły one przez cenzurę, że były pisane przez więźnia, który o tym wiedział. Stąd nie może w nich szukać szczegółowych opisów warunków bytowania więźniów, wiadomości politycznych czy innych, na które byłaby uczulona cenzura. Tę urzędową prawie suchość listów z katorgi wyczuwali ich adresaci"8. Właśnie dzięki temu mogły one dotrzeć do odbiorców. Zdarzały się też okazje do podania listu przez kogoś, jednak narażato to dostawcę na nieprzyjemności, więc Kalinowski sam odradzał rodzinie ten sposób. Gdy zamieniono mu katorgę na osiedlenie, mógł pisać częściej, ale nie robił tego.

Okres życia zakonnego. $Z$ tego okresu korespondencji do rodziny nie posiadamy wiele. Ojciec zmarł bowiem w 1878 roku, nie zdążywszy przeczytać jedynego listu wysłanego do niego z Grazu. Z macochą Zofią z Puttkamerów Józef nie utrzymywał kontaktów, bez własnej winy, gdyż nie chciała się ona pogodzić z jego wstąpieniem do zakonu; pisał natomiast listy do jej synów, a swoich przyrodnich braci, Aleksandra i Jerzego ${ }^{9}$.

Z pierwszych kilkunastu lat jego życia zakonnego posiadamy zaledwie kilkanaście listów. Zaczął pisać częściej dopiero od roku 1889, ale nie do rodziny. W tym czasie żył przede wszystkim sprawami odradzającego się zakonu. Był wówczas przeorem jedynego klasztoru karmelitów na ziemiach polskich w Czernej, potem dodatkowo

5 J. Kalinowski, Listy, wyd. Cz. Gil, t. I, cz. I (1856-1872), Lublin 1978; t. I, cz. II (1873-1877), Lublin 1978; t. II, cz. I (1878-1899), Kraków 1985; t. II, cz. II (1900-1907), Kraków 1986 [dalej każdy wolumin podawany jako Listy, przy czym cyfry rzymskie oznaczają tom i część, Lkonkretny list, a cyfra arabska numer listu w podanym wydaniu; przyp. red.].

6 Por. R. Bender, Przedmowa, w: Listy I/I, s. 5.

7 Por. Listy I/II, s. 323.

8 Cz. GLl, Wstep, w: Listy I/I, s. 29.

9 Por. tenże, Wstęp, w: Listy II/I, s. 5. 
przełożonym w Wadowicach. Na nim więc spoczywała główna odpowiedzialność za rozwój zakonu. To tłumaczy, dlaczego w tomie II Listów znajdują się tylko dwa napisane do brata Wiktora i jego żony.

\section{Wybrane tematy poruszane W listach do WiKtora i Masi}

Wszystkie listy napisane do brata i bratowej w ciągu ponad 30 lat, z wyjątkiem dwóch, pochodzą ze świeckiego okresu życia Józefa (1856-1880). Czym one są i jaką treść zawierają?

Listy jako forma kontaktu $z$ bliskimi. Listy były dla Józefa Kalinowskiego przede wszystkim sposobem komunikowania się z bliskimi. Było to ważniejsze niż poruszanie wielkich tematów, jak Bóg, ojczyzna, osobiste życie duchowe. Nie było wówczas telefonu. Edison opatentował mikrofon węglowy w roku wstąpienia Józefa do klasztoru, a do powszechnego użytku wynalazek ten wszedł znacznie później. Rafał Kalinowski prawdopodobnie nigdy w życiu nie rozmawiał przez telefon. Będąc w Petersburgu, narzekał do brata Wiktora na rzadkość jego listów, ale nie zamierzał się tym zniechęcać i rezygnować z korespondencji: „, ... ] dla mnie byłoby zbyt wiele straty, jeżelibym pozbawił siebie gawędy z Tobą"10. Czesław Gil zauważa: „Gawęda listowna z najbliższymi pozwalała mu oderwać się od codzienności wygnańczej. Na listy $\mathrm{z}$ domu rodzinnego oczekiwał $\mathrm{u}$ utęsknieniem. Jego listy niekiedy przemieniają się w rodzaj pamiętnika z podróży. Rzadko kończy je tego samego dnia. Niekiedy ten sam list pisany jest w różnych miejscach postoju"11.

Autoportret. Listy są absolutnie najważniejszym świadectwem życia i duchowości św. Rafała Kalinowskiego. Ich czytelnika, przyzwryczajonego do jedynego zdjęcia Świętego z ostatnich lat życia: oczy zamknięte, głowa podparta, twarz zadumana, spotka ogromne i miłe zaskoczenie. W listach z życia świeckiego, bo te mamy teraz na uwadze, spotykamy młodzieńca trzeźwo myślącego, z poczuciem humoru, nawet w chwilach przygnębienia czy na wygnaniu. Trudno wręcz wyrazić w słowach jego osobowość. Potrzebna jest empatia i duchowy kontakt z jego osobą podczas lektury listów.

Bardzo na miejscu byłoby zastosowanie analogii z pismami św. Teresy, chociaż $w$ nieco innym znaczeniu. Ona dialoguje $z$ Bogiem i bezwiednie wciąga czytelnika w ten dialog; Józef Kalinowski rozmawia z bliskimi, a czytelnikowi udziela się jego duch. Czytając, staje się on świadkiem zwierzeń człowieka pałającego miłością do innych, tęskniącego za rodziną, a jednocześnie świadomego, że żadne ziemskie relacje nie wypełnią pustki jego serca. Zagadnienie duchowej sylwetki, osobowości i ducho-

10 Por. Listy I/I, s. 37 (L 2).

11 Cz. Gil, Wstęp, w: tamże, s. 28. 
wości Józefa Kalinowskiego, całkowicie zorientowanej na Boga, a jednocześnie niezwykle ciepłej, gdy chodzi o relacje z innymi ludźmi, czeka jeszcze na opracowanie.

Inni ludzie to najpierw rodzina. Brata Wiktora i jego żonę Marię (Masię) Józef traktował wyjątkowo ciepło. Posiadamy jego 32 listy napisane do nich w ciaggu ponad 30 lat. Z każdego tchnie serdeczność i szczera braterska miłość. Wydaje się, że często niemal żebrał o ich słowo. Masia, nierzadko nazywana też Masieczką, traktowana była w nich jak siostra, siostrzyczka. Raz tylko, w pierwszym liście pisanym już z Karmelu, dosyć chłodnym w stosunku do wcześniejszych, nazwał ją Marią, ale szybko się to zmieniło.

Niezwykle wzruszający jest ostatni list napisany do brata w październiku 1880 roku, niecałe dwa miesiące przed śmiercią Wiktora. Podał mu w nim przykład św. Kolumbana, który wściekły z powodu złego wyniku interesów, zrobił żonie burdę pod pretekstem niegotowego obiadu, rzucił na ziemię podaną mu przez nią książkę z żywotami świętych, a potem zawstydził się, wziął ją i tak się zaczytał, że zapomniał o obiedzie. Stał się innym człowiekiem. Józef kazał bratu być podobnym do Kolumbana, a Masi do tamtej żony. Prosił ich przy tym o modlitwę za siebie, zwłaszcza po spowiedzi i przyjęciu Komunii św., bo jego zdaniem taka modlitwa ma największą moc ${ }^{12}$.

Czesław Gil pisze: „Cechą charakterystyczną listów jest żarliwy stosunek autora do wszystkich ludzi, nie wyłączając sędziów, którzy skazali go na katorgę, oraz żołnierzy, którzy go eskortowali. O nikim nie pisał z niechęcią"

Tę żarliwość bez wątpienia można nazwać serdeczną miłością, mającą korzenie już w jego człowieczeństwie. Dla przykładu, gdy spotkał sierotę Jasia, od razu kierowany współczuciem, a może czymś więcej, przygarnął go i prosił rodzinę o pomoc; w Irkucku poznał rodzinę znajdującą się w ciężkim położeniu materialnym, pisał o niej w liście do Masi i Wiktora: kobieta przyjechała do narzeczonego, wzięli ślub, mają dziecko i zupełnie nie mają warunków do życia. Od śmierci głodowej ratują ich pojedyncze osoby ${ }^{14}$.

Powstanie styczniowe. Przywołajmy tu jeden z najbardziej znanych tekstów Józefa Kalinowskiego. Gdy wychwalano pewnego dowódcę partyzantki na Podlasiu, Romana Rogińskiego, napisał o nim: „Jest to młody chłopak lat 23, bardzo ujmującej powierzchowności, ale na nieszczęście zbyt młody i niedoświadczony, niewłaściwy wybrał środek do uszczęśliwienia swej Ojczyzny; nie krwi, k tórej do zbytku się przelało na niwach Polski - ale potu ona potrzebuje! Na nieszczęście kraju, młodzież tego zrozumieć nie chce"15.

12 Por. Listy II/I, s. 45 (L 442).

13 Por. Cz. Gil, Wstep, w: Listy I/I, s. 32.

14 Por. Listy I/I, s. 266 (L 108).

15 Tamże, s. 102 (L 36). 
Warunki życia. W roku 1861 przyjechał do Warszawy. Ludzie ubrani byli niemal żałobnie. On w wojskowym stroju czuł się trochę nieswojo. Przed nim była jeszcze podróż do Częstochowy, pod Kraków, do Ciechocinka, a potem do Wilna. Cieszył się z tego. Życie w fortecy było dla niego najwyraźniej męczące. Traktował zatem podróże jako lekarstwo moralne ${ }^{16}$.

Do tego listu wydawca dołączył list Ludwiki Młockiej, bo Józef świadomie nie opisał swojego pobytu w stolicy, wiedząc, że ona to zrobi. Ona tymczasem pisze głównie o sprawie ewentualnego małżeństwa Józefa z siostrą Masi Celiną Gruszecką, która mimo wszystko została w 1862 roku wydana za Adama Domańskiego, a rok później zmarła ${ }^{17}$.

Po zmianie katorgi syberyjskiej na lżejsze osiedlenie Józef zamieszkał w Irkucku. W liście do Wiktora i Masi opisał swoją sytuację i plan dnia (22 grudnia 1868): „Mieszkam sam jeden, ale w swojskim otoczeniu; mam jeden pokoik na dole z oknami na zachód. Miast opowiadania proszę planik [został on opisany w przypisie]. Wstaję koło siódmej, staram się co dzień być w kościele, biegnę do zajęcia, które trwa do pierwszej, obiad, wracam do domu i reszta dnia do mnie należy. - Dochód mój wynosi rs. 20, wystarcza mi na utrzymanie, ale nie na wszystkie potrzeby..."18.

O wiele bardziej szczegółowo opisał pobyt w Usolu: „Obecna rzeczywistość jest taka: miasto, w którym jestem internowany, jest siedzibą urzędników kopalni. Tworzą oni odrębną warstwę, od której jesteśmy całkowicie izolowani, z wyjątkiem wypadków służbowych [...]. Nasza społeczność jest bardzo zróżnicowana. Jest wiele rodzin, w których są niewiasty i dzieci. Nadaje to naszemu kółku jakieś zabarwienie rodzinne i zapełnia pustkę, jaka zawsze istnieje w zgromadzeniu osobników tej samej płci. Możemy się widywać i odwiedzać się wzajemnie, możemy swobodnie zajmować oddzielne mieszkania. Ja również korzystam z tej swobody" ${ }^{19}$. Po czym podał szczegółowy program dnia, podobny do cytowanego wyżej.

Estetyka. Przy okazji należy zauważyć, że Józef miał talent do robienia szkiców i rysunków. Wyglądają one niemal jak fotografia. Dla nas może to być dziwne, że potem, w zakonie, nie rozwijał tego talentu. Przy innej okazji wypowiedział się tė̇ w kwestii muzyki. W 1875 roku uczestniczył w Paryżu razem z Augustem Czartoryskim w koncercie utworów Georga Fridricha Händla. „Koncert nieszczególne na mnie zrobił wrażenie, wielkość przedmiotu, jako treści, nie odpowiada dźwiękowej wystawie i stąd jest pewna walka formy $z$ treścią, walka, która nie istnieje we właściwej muzyce kościelnej, chociażby licho, ale we właściwym otoczeniu wykonanej"20.

\footnotetext{
16 Por. tamże, s. 77 (L 17).

17 Por. tamże, s. 80-81 (L 19).

18 Tamże, s. 266 (L 108).

19 Tamże, s. 233 (L 92).

20 Listy I/II, s. 151 n. (L 298).
} 
Każdy ma prawo do swojego zdania na temat muzyki. W przeciwnym razie wszyscy słuchaliby tylko jednego jej rodzaju.

Opinia o Paryżu. W tym samym liście do brata i jego żony, pisanym z Paryża 15 stycznia 1875 roku, wypowiedział się o pewnych aspektach życia w stolicy Francji, $z$ jednej strony negatywnie, $z$ drugiej pozytywnie. By w pełni uchwycić jego opinię, należałoby go odczytać prawie w całości. Wypowiadał się także w sprawach religijnych, kulturowych, społecznych: „Paryż nie jest tym, czym był dawniej. [...] Kazania mi się nie podobają z tego względu, że na nich nieraz podnoszą się kwestie socjalne i narodowe z pewną szkodą materii teologicznej”; o operze i teatrze: „Opera tak zachwalana - wyraz zupełnego braku smaku, teatra - nie dla chrześcijan, dla których Zbawiciel przelał Krew Swoją, życie uliczne - dobre dla odurzenia, ludzie obcy, majętność cudzoziemszczyzny w powszedniej i ujemnej stronie. [...] Ale można tu przyjechać, żeby się uczyć, jak potrzeba pracować, jak radzić potrzebom bliźnich, jak poświęcać się dla Boga i ludzi, nie upadając pod ciężarem klęski, goić rany i ratować podwaliny gmachu społecznego i kościelnego przez poświęcenie się w pracy koło młodzieży, dzieci, robotników dla miłości Boga i z pobudek wiary"21.

O matżeństwie. Kilkakrotnie pojawia się wątek małżeństwa. W wieku 21 lat, wypowiadając wobec Wiktora zachwyt nad życiem małżeńskim, wrócił od razu na ziemię: „[... ] z daleka ono ma tyle powabu, jest rajem ziemskim, lecz z bliska musi się wiele nowych zaciemniających obraz kolorów dojrzeć, i jeżeli nie całą, to przynajmniej przyzwoitą część iluzji stracić”. Potem następuje zdanie warte zapamiętania, bo wydaje się streszczać całe jego świeckie życie duchowe: „Zresztą, czy jest cokolwiek na świecie, co by nie ciagnęło za sobą rozczarowania; ile razy stwarzałem sobie tyle szczęścia! Jeżelibym dosięgnąć mógł tego lub innego przedmiotu i - kiedym dopiął celu zawsze zostawała jakaś próżnia, której niczym się nie udawało zapełnić. [...] co do mnie, to czuję, że nigdy siebie nie zaspokoję, zawsze mi będzie czegoś brakować”22.

W kolejnym liście, $z$ Petersburga, gdy brat był w przededniu zawarcia związku małżeńskiego, cieszył się z tego, ale sam nie odnosił się do małżeństwa z entuzjazmem. Wiktor, zakochany, napisał do Józefa jakiś poetycki list, a ten przyznaje, że się z niego uśmiał, i od razu tłumaczy, że chciałby i on przyłączyć się do jego romantycznych myśli, „ale świętokradzkie pióro moje nie chce mię słuchać”23. Jak widać, nie brakowało mu bardzo subtelnego poczucia humoru.

21 Tamże, s. 151 n. (L 298).

22 Listy I/I, s. 37 n. (L 2).

23 Tamże, s. 44 (L 5). 
W liście z grudnia 1857 roku, gdy Wiktor był już żonaty, znajdujemy znowu zachwyt nad życiem małżeńskim, ale trudno powiedzieć, czy jest on do końca szczery; był to raczej rodzaj komplementu dla Wiktora i wyraz poczucia humoru Józefa: „Niech znajdę drugą kobietę, choć trochę przybliżającą się do twej złotej żony, to dzisiaj się ożenię, jeżeli tylko przyjąc mnie zechce za męża"24.

$\mathrm{Na}$ temat lekcji, których udzielał dzieciom zesłańców, napisał: „Dziwnie miła dziatwa, kocham ją tu uczuciem rodzinnym, dom ich dla mnie nieraz jest przypomnieniem naszej rodziny również licznej. W młodszej dzieweczce stanowczo się kocham, żałuję nieraz, że 24 lata wieku nas różnią. Ale żal daremny. Lat nie cofnę. - Widzicie, jakim próżnym myślom ulegam, ale serce nie kamień i po Bogu potrzebuje mieć kogoś przy sobie do kochania, kogoś realnego. [...] Ale żart na stronę"25. Ponieważ był to rok 1870, a zatem Józef miał 35 lat, wnioskujemy, iż wspomniana dzieweczka liczyła ich 11 .

Emancypacja kobiet. Pisał do Masi z Irkucka w 1870 roku: „Obecnie w Irkucku jest bardzo wzięta teoria emancypacji płci pięknej spod jarzma płci brzydkiej, dla mnie ta kwestia trąci donquichoterią z jednej strony i pogwałceniem praw naturalnych $z$ drugiej; a co do wychowania i wykształcenia kobiet, jeżeli zostaje dużo do zrobienia, to nie mniej też zmian ku lepszemu wypadałoby dokonać i w kształceniu mężczyzn"26.

Jak widać, nawet na zesłaniu nie opuszczał go humor ani tym bardziej trzeźwe myślenie.

\section{ZAKOŃCZENIE}

Lektura listów Józefa Kalinowskiego do najbliższej rodziny - nas w szczególności interesowały tu listy do jedynego rodzonego brata Wiktora i jego żony Masi - każe stwierdzić, że nie ich zawartość treściowa jest najważniejsza. Tematyka wszystkich listów jest bardzo podobna: sprawy osobiste, bieżąca sytuacja, sprawy powstania styczniowego, narodu, bliźnich, kwestie związane z praktyką wiary. Chodzi o samo komunikowanie się i pozostawanie w łączności. Refleksja listowna zastępuje spotkanie osobiste, współczesną rozmowę przez telefon, Skype; dla Józefa otrzymywanie listów od bliskich to duchowa uczta i jedyna dostępna forma „bycia” z nimi. On zaś, odpisując, a częściej prowokując ich odpowiedzi, ujawnia swój wewnętrzny świat.

24 Tamże, s. 47 (L 6).

25 Tamże, s. 313 (L 130).

26 Tamże, s. 312 (L 130). 
Korespondencja Świętego bez wątpienia jest pierwszorzędnym źródłem do poznania jego życia podczas katorgi i osiedlenia, dalej stosunków panujących wówczesnej Polsce, Rosji, Francji oraz wielu innych spraw, o których wspomina, ale przede wszystkim listy te zawierają autobiografię duchową Józefa, później Rafała Kalinowskiego. Ich lektura nie tyle dostarcza jakiejś mniej lub bardziej abstrakcyjnej wiedzy, ile jest spotkaniem $z$ jego osobą, która okazuje się inna, niż to wynika $z$ utartej powierzchownej opinii o nim.

\title{
BIBLIOGRAFIA
}

Bender R., Przedmowa, w: Listy, wyd. Cz. Gil, t. I, cz. I (1856-1872), Lublin 1978, s. 5-7.

GIL Cz., Wstep, w: Listy, wyd. Cz. Gil, t. I, cz. I (1856-1872), Lublin 1978, s. 9-33. KalinowsKi J., Kartki z Ksieggi mojego życia, oprac. Cz. Gil, Kraków 2007.

KalinowsKi J., Listy, wyd. Cz. Gil, t. I, cz. I (1856-1872), Lublin 1978.

Kalinowski J., Listy, wyd. Cz. Gil, t. I, cz. II (1873-1877), Lublin 1978.

Kalinowski J., Listy, wyd. Cz. Gil, t. II, cz. I (1878-1899), Kraków 1985.

Kalinowski J., Listy, wyd. Cz. Gil, t. II, cz. II (1900-1907), Kraków 1986.

\author{
ABSTRACT \\ Jerzy Wiestaw Gogola OCD \\ The Topics of St Raphael Kalinowski's Letters to His Family
}

Writing about the topics of Józef Kalinowski's letters to his family required a certain approach: first, at least a brief introduction regarding the four-volume collection of these letters; second, the explanation of what the word "family" meant to Kalinowski; third, focusing on a selected group of letters, namely on the thirty-two letters addressed to the Saint's brother Wiktor and his wife Maria (Masia.)

The analysis of these letters leads to the conclusion that their topics are not of the highest importance. Kalinowski alludes to similar things in every one of them: personal issues, current situation, matters pertaining to the January Uprising, to the nation, to fellow man, as well as matters regarding the practice of one's faith. What does come across as most important is the contact with his kin by means of exchanging letters. 
Moreover, all of these letters disclose the true spiritual profile of the Saint; and it differs from the way he was commonly, and superficially, perceived by others.

\section{Słowa klucze:}

Imienne: Kalinowski: Andrzej, Józef, Wiktor, Gabriel, Jerzy, Karol, Aleksander; Kalinowskie: Emilia, Maria i Monika, Zofia z Puttkamerów, Maria Gruszecka, Zofia Gruszecka, Młocka

Rzeczowe: Petersburg, powstanie styczniowe, Usole, Brześć, Graz, Czerna, Wadowice, Paryż, Karmel, ojczyzna, małżeństwo, emancypacja, estetyka

\section{Keywords:}

Personal: Kalinowski: Andrzej, Józef, Wiktor, Gabriel, Jerzy, Karol, Aleksander; Kalinowskie: Emilia, Maria and Monika; Zofia Puttkamer, Maria Gruszecka, Zofia Gruszecka, Młocka

Other: Petersburg, January Uprising, Usole, Brześć, Graz, Czerna, Wadowice, Paris, Carmel, homeland, marriage, emancipation, esthetics 